\title{
P53-Regulated Apoptosis-Inducing Protein 1
}

National Cancer Institute

\section{Source}

National Cancer Institute. p53-Regulated Apoptosis-Inducing Protein 1. NCI Thesaurus. Code C121116.

p53-regulated apoptosis-inducing protein 1 (124 aa, 13 kDa) is encoded by the human TP53AIP1 gene. This protein plays a role in the mediation of p53-dependent apoptosis. 